\title{
Study of Signs of Discrimination in Labor Relations of Georgia
}

\author{
Ekaterine Gulua \\ $\mathrm{PhD}$ in Economics, CEO of HPML, \\ Assistant-Professor of TSU \\ Shalva Baghaturia \\ PhD Candidate in Social Sciences, TSU, \\ HR Consultant of STREAM \\ Nato Sikmashvili \\ Researcher, MBA \\ Maia Shavliashvili \\ Researcher, MBA
}

\section{Abstract}

The paper is dedicated to the study of equality and discrimination in labor relations of Georgia. The aim of the research is to study the demand of job suppliers on the Georgian labor market including the assessment of compliance with the principles of labor equality. Both qualitative and quantitative methods were used during the research process. One of the forms of labor discrimination - discrimination before employment - was selected as the object of research during the vacancy announcement. 3719 vacancy announcements published from October to December 2020 were studied and they were analyzed on the basis of pre-established criteria. The research was conducted by "HR-Hub" and "Stream" research group. Group Leader: Shalva Baghaturia, participants: Nato Sikmashvili, Maia Shavliashvili, Ekaterine Gulua. The paper discusses theoretical issues related to the topic, international experiences, as well as the research results and relevant recommendations. The results of the research were broadcasted on Imedi TV in Georgia

Keywords: discrimination before employment, age, gender, appearance

\section{Introduction}

Maintaining equality in labor relations, the possibility of free expression of will is the cornerstone of organizational development. Fair systems of labor organization lead to attracting talents, encouraging them, introducing fair motivational mechanisms, 
which in turn mean making quality decisions, reducing costs and improving the results of the organization. Establishing the principles of justice, democracy in the organization, implementing employee voice, respectful attitude towards them, emphasizing and demonstrating their importance significantly change the involvement, lead to the restriction of absenteeism (Bailey, Caterine; Mankin, David; Kelliher, Clare; Garavan, Tomas;, 2018). There is a positive correlation between diversity, success of the management team and financial results in the organization (Warth, Lisa;, 2009), (Standing, Hilary; Baume, Elaine;, 2001). This effect is only once or twice more evident when employees' ombudsmen, trade unions, and nongovernmental organizations, along with the judiciary, actively lobby for employees' rights. According to the 2021 data of Equal Employment Opportunity Commission from January 1 to February 10 this year, companies were required to pay $\$ 1.5$ million in compensation for employee discrimination, also many companies are in litigation (U.S. Equal Employment Opportunity Commission, 2021). In 2006, for example, a discriminatory approach cost $\$ 64$ billion for U.S. employer companies. Which was then the equivalent of the assets of Google, Goldman Sachs, Amazon.com and Starbucks (Level Playing Field Institute, 2007); And the effort and capital spent on disputes could have consumed the success of the organization. Steps made towards diversity are associated with changes in values, rejection of stigmas, organizational ethics, social responsibility, the establishment of justice, although it can have a significant effect in the short term. Although Coca-Cola had to pay $\$ 192.5$ million in fines in 2000 for discriminatory treatment towards African-American employees, it was named one of the top 10 companies for positive diversity in just two years (Robbinc, Stephen p.; Coulter, Mary;, 2013), which certainly improved its image as an employer.

Still in the twentieth century, precise methodological foundations were laid, by which the financial costs and losses of companies caused by discriminatory treatment of employees are calculated. This applies to the losses due to a discriminatory approach to workforce marketing, recruitment, selection, adaptation/socialization, training, including promotion of less competent people, as well as costs related to dismissal and compensation related to it (Crosby Burns, March 2012). In the 1990s, the cost of employee rotation in the United States was estimated at $\$ 5,000$, the cost of hiring an hourly worker at $\$ 10,000$, and the cost of executive staff from $\$ 75,000$ to $\$ 210,000$ (Robinson, Gail; Dechant, Kathleen;, 1997).

It is known that when a low-skilled employee leaves the organization, the organization has to pay 30 to $50 \%$ more than the average annual salary of a gone employee to replace him/her. The cost of replacing an average-skilled labourer is $150 \%$ more than his/her annual salary, and in case of replacing a highly-qualified specialist - 400\% more than his/her annual salary (Gulua, Ekaterine;, 2017).

Of particular note are the hidden costs that companies have to pay in the event of tarnishing the image of a good employer. When announcing a vacancy, the number of 
applicants does not make it possible to hire competitive staff. This is a significant challenge for human resource management along with the necessity of retaining talent (Gulua, Ekaterine;, 2020). (Gulua, Ekaterine;, 2020). Also, in modern human resource management actual trends are: digitalization of processes (Gigauri, Iza; Gulua, Ekaterine; Mushkudiani, Zurab;, 2020) and using more humanized management methods (Mushkudiani, Zurab ; Gechbaia, Badri; Gigauri, Iza; Gulua, Ekaterine;, 2020) .

\section{Literature Review}

Discrimination against people in the workplace can take many forms. The grounds for discrimination can be: revenge, mental or physical disability, mental or physical condition, race (Negroid (Black) race; Australoid (Australian Aborigine and Papuan) race; Capoid (Bushmen/Hottentots) race; Mongoloid (Oriental/Amerindian) race; Caucasoid (White) race.), gender, gender and sexual orientation, age, ethnicity, skin color, religious belief, pregnancy, or parenthood, relationship with someone who can be discriminated, genetic information, social belongingness, etc. The protection of human rights in the civilized world is carried out by the following international acts: the Universal Declaration of Human Rights adopted by the UN on 10 December 1948 (United Nations General Assembly, 10/12/1948), the European Convention on Human Rights adopted by the Council of Europe on 4 November 1950 (Council of Europe, 4/11/1950), The European Social Charter (Council of Europe, 26/02/1961) declared by the Council of Europe on 26 February 1966; The UN Covenants on Civil and Political Rights (United Nations, 16.12.1966)., and on Economic Social and Cultural Rights adopted on 16 December 1966 (United Nations, 16/12/1966).

Perceptions of the topicality of discrimination at the national legal level began in the United States in the 1960s, mainly in the area of protection against minority oppression, it developed as the American anti-discrimination paradigm, while in Europe the protection against discrimination is the paradigm of protection of human dignity (Friedman·, Gabrielle S; Whitman, James Q;, 2002-2003).

The International Labor Organization Convention of 4 June 1958 is in force against discrimination in employment and occupation (International Labor Organisation, 1958). This Convention was ratified by the Government of Georgia on 22 June 1993 (International Labour Organisation, 1993).

After the liberation from the Soviet occupation, for the first time in the post-Soviet space, the Supreme Council of Georgia was formed as a result of the multi-party elections held on October 28, 1990. On March 31, 1991, a referendum on the restoration of Georgia's independence was held on the basis of the 1918 Independence Act. On April 9, 1991, the Act on the Restoration of the State Independence of Georgia was adopted, declaring the restoration of the independence of Georgia. By the resolution of September 15, 1991, the Supreme Council of Georgia 
recognized the UN Declaration of Human Rights, and it became a member of the UN in 1992.

At present, the right to equality of people in Georgia is protected by the Constitution - in particular, Article Eleven (Parliament of the Republic of Georgia, 24/08/1995). Any kind of discrimination against people is prohibited. The state is the defender of equal rights. Its obligation is to ensure equality, to eliminate inequality. Along with the Constitution, legislative and normative acts are in place to ensure equality. These include the Law of Georgia on the Elimination of All Forms of Discrimination (Parliament of Georgia, 02/05/2014) and Organic Law of Georgia - the Labor Code (Parliament of Georgia, 17/12/2010). There is also a legal entity under public law in Georgia - the Labor Inspectorate, which on the basis of the Labor Inspection Law (Parliament of Georgia, 29/09/2020) and other relevant legislation is authorized to respond to violations of labor norms on its own initiative or on appeal.

\section{Historical perspective}

As for Georgia's historical experience of discrimination - there are facts in favor of Georgia. We think that the most important thing in this regard, which has to do with the mentality of the nation - is that the Georgian language is gender neutral. Personal and possessive pronouns as accepted in most language grammars, differentiate between sexes. For example, in English: "he/she", "her/his", in Russian: "Он/Она", "Её/Его", which emphasizes gender, in Georgian, the third person pronoun is expressed by a neutral pronoun - "ob", a third person possessive pronoun, regardless of gender is - „dobo". It is a precedent, though it is notable, that in the twelfth century Georgia was ruled by a woman - King - Tamar, as well as historically known - the temporary rule of women - queens, or their participation in diplomatic negotiations. It is also interesting that in 1918, as soon as Georgia was given the opportunity to break away from the Russian occupation of 1801 and declare an independent republic, it was one of the first European countries to elect a legislature through universal suffrage. Women participated in these elections as equal voters. According to the election law adopted on November 22, 1918, all adult citizens of Georgia, regardless of gender, participated in the elections. In addition, 5 out of 130 members elected for the legislature through general elections in Georgia were women. It is true that this is not a proper number, but at the beginning of the twentieth century this figure was not available in many European countries. It is also interesting to note that despite the medieval religious wars there is a great variety of artefacts of peaceful coexistence of members of different confessions in Tbilisi and in Georgia in general.

It is noteworthy that in Georgia, as early as 1921, the Constitution of Georgia, approved by the Constituent Assembly of Georgia, guaranteed fundamental human rights and freedoms. The document emphasizes the equality of every citizen of Georgia before the law. Equality of citizens is emphasized in the Constitution, regardless of gender, ethnicity, religion, rank. The Constitution also stipulated the age of employment, the obligation to promote employment, the protection of the disabled, 
the protection of people in case of losing the ability to work while performing official duties, employment of adolescents under 16 years of age was prohibited, working day of 16-18 year olds was defined as 6 hours per day, women and young people were prohibited from working night shifts. Women's rights, working conditions after childbirth were emphasized. The Constitution protected the equal rights of citizens of both sexes in political, civil, economic and family relations. Violation of both civil and labor rights was defined by the Constitution as a criminal offense (Constituent Assembly of Georgia, 21/02/1921). This does not mean that a standard of equality that was in Georgia, or it is even today, meets modern requirements.

As for the discrimination in labor relations, Labor Code of Georgia - Article 2 (paragraphs 3-6) prohibits discrimination in labor, as well as in pre-contractual relations (2012).

According to the amendment to the Labor Code of Georgia in September 29, 2020, on the basis of the Organic Law N 7177 (Parliament of Georgia, 29/09/2020), a separate (II) chapter was dedicated to the prohibition of labor discrimination. The scope of the law was specified. It included: labor relations before employment, in the process of employment, during professional activities. The law explicitly states that the law regulates labor relations at the stages of publication a vacancy application and selection by the organization, in pre-contractual relations, as well as selection criteria and employment conditions (Article 5). The same chapter (Article 7) states that in the event of a dispute, the burden of proof rests with the employer if the candidate or employee points to specific facts or circumstances of discrimination. Hopefully, this legislative change in 2020 will have a positive impact on the attitude towards employees and candidates.

\section{The conducted study}

The purpose of a study conducted by HR Hub and Stream Research Group on Labor Equality and Labor Discrimination in the Georgian labor market was to study the demand of job suppliers, including assessment of compliance with the principles of equality of applicants.

The object of the study was the electronic announcements made publically by employers on employment sites. There are two dominant employment sites in the Georgian online space, including the largest site - https://www.jobs.ge/, which publishes vacancies, trainings, exchange programs, grants and tenders announced by the largest number of organizations. The site was made in 1998 and has developed as the most successful online business in Georgia.

A similar study was conducted by N(N)LE "Article 42 of the Constitution" and "Jumpstart Georgia". The survey included 71,360 ads published on www.Jobs.ge and 14,376 ads published on www.hr.gov.ge in 2010-2014. 85,736 ads were reviewed in total. The authors of the study noted that in this combination the word female was mentioned in $10.01 \%$, and male - in $24.02 \%$. More specifically, on www.Jobs.ge the 
word man was mentioned 1088 times, on www.hr.gov.ge - 394 times. The word pleasant appearance - 1589 times (1.85\%), it should also be noted that with the authors' explanation this expert study was based on the keyword search method (Jalagania, Lika; Nadareishvili, Tinatin;, 2014). We think this is an important shortcoming of the study as the context of each case has not been explored.

\section{Research deadlines}

The most active time for announcing vacancies on the labor market was selected as the time of the research. Two dates were selected, namely October 31 and December 2 , when all non-recurring vacancy announcements on the site were downloaded. On October 31, 2095 ads were recorded, covering the period from October 1 to October 30, except for short-term announcements, and on December 2 there were 1624 applications covering the period from November 2 to December 2. 3719 applications were reviewed in total.

The applications were evaluated according to up to 50 pre-designed criteria. The data was processed using Exel. A total of 3719 - all non-recurring ads made from October to December were examined. We provide an analysis of the study of discrimination signs in the research object.

We studied discrimination on the basis of gender, age and appearance. A total of 655 discriminatory records were found in announcements. The number of announcements including discriminatory text was 13\% (487 announcements) [Diagram 1].

\section{DIAGRAM 1. DISCRIMINATORY AND NONDISCRIMINATORY RECORDS} IN THE ANNOUNCEMENTS

Discriminatory

$13 \%$

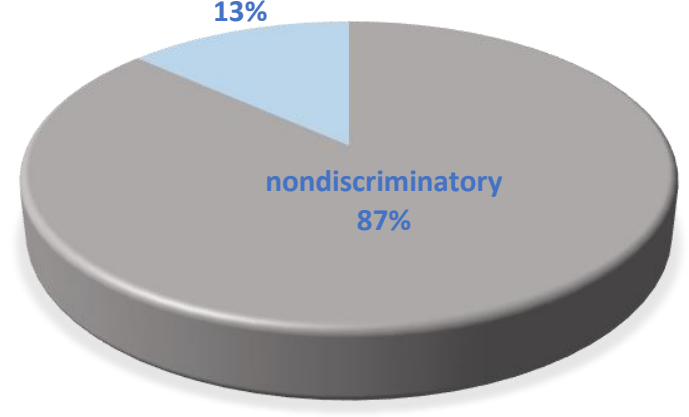

Discrimination was found on all three grounds (age, sex, physical characteristics) in 13 announcements, two signs were found in 356 announcements, and one sign - in 128 announcements [Diagram 2]. 


\section{Diagram 2. Discrimination in the Announcements}

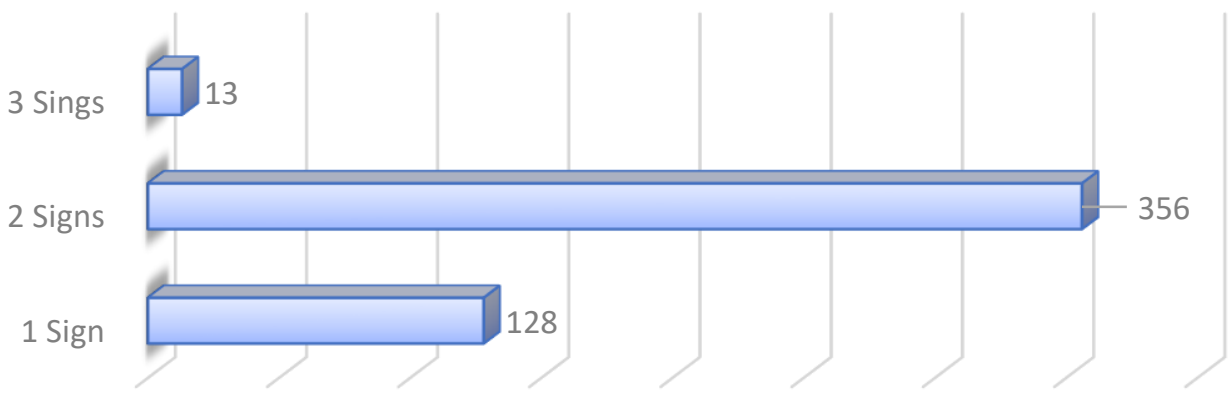

Restrictions due to Appearance: Comments were made on appearance in 87 cases - they were asking for a nice looking applicant. Gender restriction was reported in 175 cases, accounting for $5 \%$ of the total. The age limit was expressed in 393 announcements [Diagram 3].

\section{Diagram 3. Amount of Discriminatory Statements}
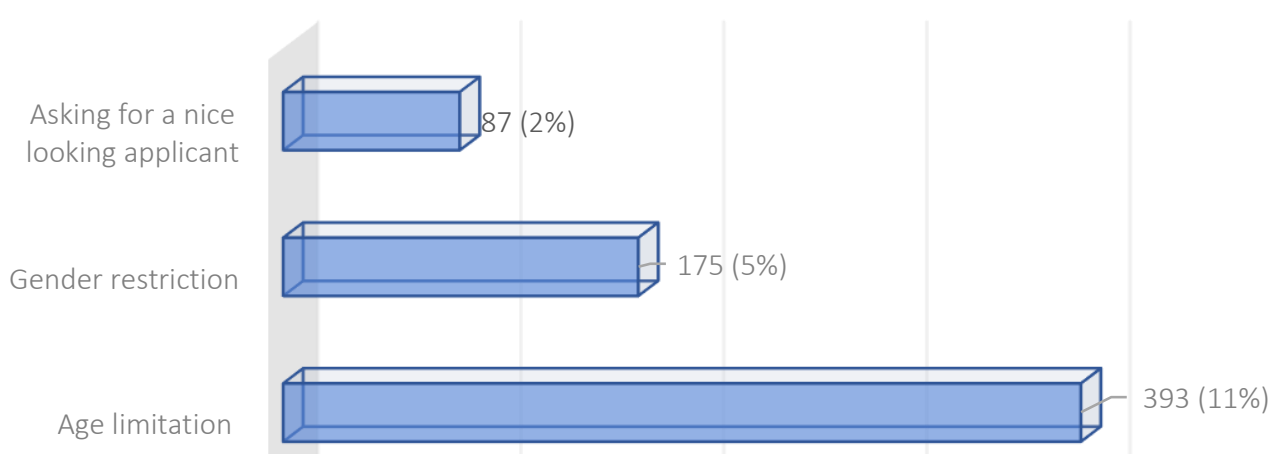

Age restriction: Age restriction occurred in 393 announcements. In particular, a specific age was named, or it was stated that the applicant must have been young (35 units). The phrase "the age of the applicant does not matter" was observed in 22 cases [Diagram 4]. 


\section{Diagram 4. Age Restriction}

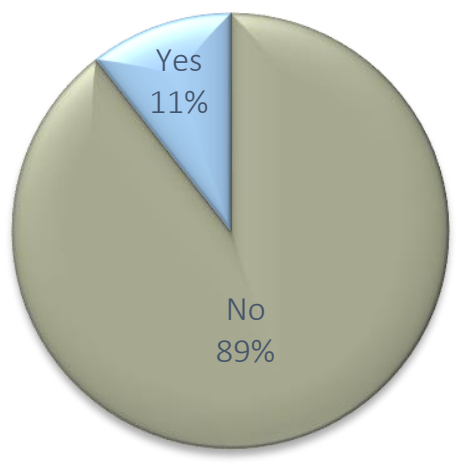

Gender Restriction: In the published announcements, the demand for a specific gender was observed in 175 cases, the demand for women was in 89, and for males in 86 cases. Although the difference is small, it is interesting to note that men were discriminated compared to women. In total, such cases represent $4.7 \%$ of the total amount [Diagram 5].

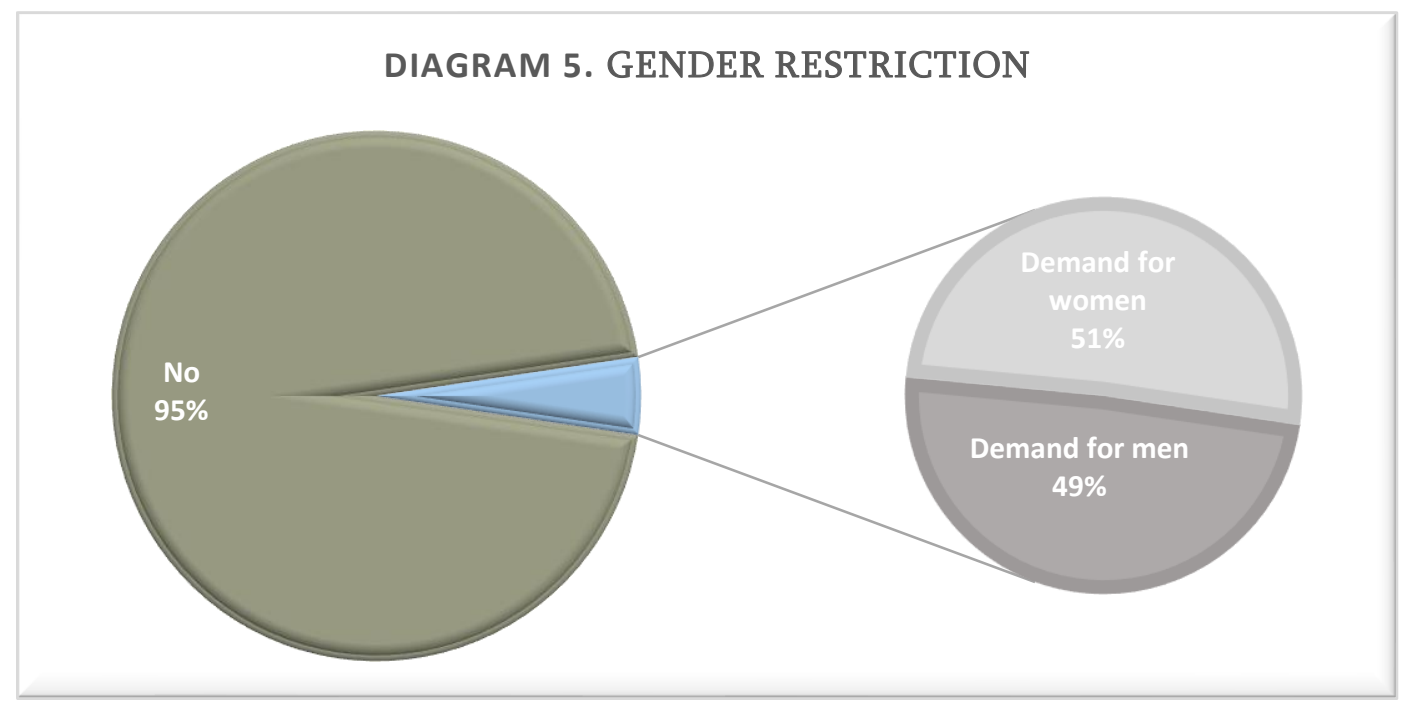

Discrimination on the basis of appearance: The requirement on the basis of appearance is highlighted in 87 statements, which is $2.3 \%$ of the total amount [Diagram 6]. 


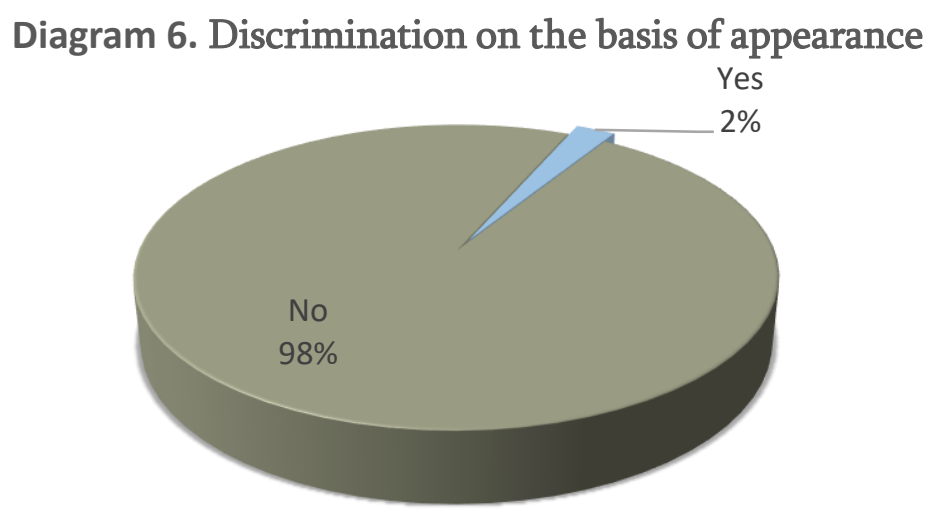

It should be noted that other forms of discrimination were not revealed by us on the basis of this study.

\section{Conclusions and recommendations}

- The research revealed specific facts of discrimination, in particular the discrimination of applicants on the basis of gender, age and appearance when announcing a vacancy.

- Since Article Eleven of the Labor Code directly obliges the employer to provide information to the candidate during the pre-contractual period: about the work to be done, working conditions, form and terms of the employment agreement, the employee's legal status, remuneration - it is desirable that the above-mentioned issues appear in the vacancy announcement, which promotes clarity and transparency and will save time for both applicants and employers.

- The promotion of the guidelines created by the International Labor Organization (for example, "Promoting diversity and inclusion through workplace adjustments: a practical guide" dedicated to equalization of persons with disabilities, AIDS, pregnant women and arrested family members, people with different religious beliefs) will help the organizations in Georgia to take concrete, practical advice into consideration and implement appropriate attitudes (International Labour Office, 2016). It should be noted that similar types of manuals are useful for any type of organization.

- In modern Georgia, there are still important steps to be taken to eliminate discrimination in the direction of law enforcement, to establish an equal partnership in labor relations, which is hindered, on the one hand, by the poor practice of functioning in a market economy, as well as by the imbalance of workforce and jobs on the labor market.

- I think the 2020 legislative change will play some role in formally limiting discrimination, though at an in-depth level restriction of discrimination 
requires an active civil society, a proper response of the judiciary to the facts of discrimination, the active efforts of trade unions and other workers' rights organizations and relevant government agencies, understanding the benefits of diversity in the workplace from the business side.

\section{Bibliography}

[1] Bailey, Caterine; Mankin, David; Kelliher, Clare; Garavan, Tomas;. (2018). Strategic Human Resource Management, Second Edition. OXFORD UNIVERSITY PRESS.

[2] Constituent Assembly of Georgia. (21/02/1921). Constitution of Georgia. Tbilisi: Legislative Herald of Georgia. Retrieved from https://www.matsne.gov.ge/en/document/view/4801430?publication=0

[3] Council of Europe. (26/02/1961). The European Social Charter. Council of Europe. Retrieved from https://www.coe.int/en/web/european-socialcharter

[4] Council of Europe. (4/11/1950). European Convention on Human Rights. Rome. Retrieved from https://www.echr.coe.int/documents/convention_eng.pdf

[5] Crosby Burns. (March 2012). The Costly Business of Discrimination/ The Economic Costs of Discrimination and the Financial Benefits. Center for American Progress.

[6] Friedman·, Gabrielle S; Whitman, James Q;. (2002-2003). The European Transformation of Harassment Law: Discrimination Versus Dignity. Retrieved from https://digitalcommons.law.yale.edu/cgi/viewcontent.cgi?article=1649\&c ontext=fss_papers

[7] Gigauri, Iza; Gulua, Ekaterine; Mushkudiani, Zurab;. (2020). Current Advances In Digital Recruitment Of Human Resources And Its Potential For Companies. SEU \& Science. Retrieved from https://papers.ssrn.com/sol3/papers.cfm?abstract_id=3700584

[8] Gulua, Ekaterine;. (2020, March 31). TRENDS, CHALLENGES AND ORIENTATIONS OF HUMAN RESOURCE MANAGEMENT. Innovative Economics And Management, Vol 7 No 1 (2020), pp. 51-67.

[9] Gulua, Ekaterine;. (2017). Strategic Human Resource Management (Lecture Course). Tbilisi: TSU.

[10] Gulua, Ekaterine;. (2020, March 31). PECULIARITIES OF ACADEMIC STAFF SELECTION AT HIGHER EDUCATION INSTITUTIONS. Innovative Economics And Management, Vol 7 No 1 (2020), pp. 68-89. 
[11] International Labor Organisation. (1958). Discrimination (Employment and Occupation) Convention. Geneva: ILO.

[12] International Labour Office. (2016). Promoting diversity and inclusion through workplace adjustments: a practical guide . Geneva: ILO.

[13] International Labour Organisation. (1993). Ratifications for Georgia. Geneva. Retrieved from https://www.ilo.org/dyn/normlex/en/f?p=NORMLEXPUB:11200:0::NO::P 11200_COUNTRY_ID:102639

[14] Jalagania, Lika; Nadareishvili, Tinatin;. (2014). Gender Discrimination in Labor Relations. Tbilisi: Article 42 of the Constitution. Retrieved from http://tanastsoroba.ge/en/publications/2

[15] Level Playing Field Institute. (2007). The Cost of Employee Turnover Due Solely to Unfairness in the Workplace. Korn Ferry International. Retrieved from https://www.smash.org/wp-content/uploads/2015/05/cl-executivesummary.pdf

[16] Mushkudiani, Zurab ; Gechbaia, Badri; Gigauri, Iza; Gulua, Ekaterine;. (2020). Global, economic and technological trends in human resource management development. ACCESS Journal: Access to Science, Business, Innovation in Digital Economy, 53-60.

doi:https://doi.org/10.46656/access.2020.1.1(4)

[17] Parliament of Georgia. (02/05/2014). Law of Georgia on the Elimination of All Forms of Discrimination. Tbilisi: Legislative Herald of Georgia.

Retrieved from https://matsne.gov.ge/en/document/view/2339687?publication=0

[18] Parliament of Georgia. (17/12/2010). ORGANIC LAW OF GEORGIA LABOUR CODE OF GEORGIA. Tbilisi: Legislative Herald of Georgia. Retrieved from https://matsne.gov.ge/en/document/view/1155567?publication=16\#!

[19] Parliament of Georgia. (29/09/2020). ON THE LABOUR INSPECTION SERVICE. Tbilisi: Legislative Herald of Georgia.

[20] Parliament of Georgia. (29/09/2020). Organic Law of Georgia. Tbilisi: Legislative Herald of Georgia. Retrieved from https://matsne.gov.ge/en/document/view/5003141?publication=0

[21] Parliament of the Republic of Georgia. (24/08/1995). Constitutional Court of the Republic of Georgia. Tbilisi: Legislative Herald of georgia. Retrieved from https://matsne.gov.ge/en/document/view/30346?publication=36

[22] Robbinc, Stephen p.; Coulter, Mary;. (2013). Management 12th eddition. 
[23] Robinson, Gail; Dechant, Kathleen;. (1997). Building a business case for diversity. Academy of Management Executive 11 (3), 21-31.

[24] Standing, Hilary; Baume, Elaine;. (2001). Equity, Equal Opportunities, Gender and Organizational Performance. Geneva: World Health Organization.

[25] U.S. Equal $\neg$ Employment $\neg$ Opportunity $\neg$ Commission. (2021). Report. Retrieved from https://www.eeoc.gov/

[26] United Nations. (16.12.1966). International Covenant on Civil and Political Rights. United Nations of Human Rights. Retrieved from https://www.ohchr.org/en/professionalinterest/pages/ccpr.aspx

[27] United Nations. (16/12/1966). International Covenant on Economic, Social and Cultural Rights. United Nations Human Rights Office. Retrieved from https://www.ohchr.org/EN/ProfessionalInterest/Pages/CESCR.aspx

[28] United Nations General Assembly. (10/12/1948). The Universal Declaration of Human Rights. Paris: UN. Retrieved from https://www.un.org/en/universal-declaration-human-rights/

[29] Warth, Lisa;. (2009). UNITED NATIONS ECONOMIC COMMISSION FOR EUROPE, DISCUSSION PAPER SERIES, Gender Equality and the Corporate Sector. Geneva, Switzerland: UN. Retrieved from https://unece.org/fileadmin/DAM/oes/disc_papers/ECE_DP_2009-4.pdf 